Borneo Journal of Sciences \& Technology, Volume (3), Issue (1), Pages: 51-60

DOI: http://doi.org/10.3570/bjost.2021.3.1-08

e-ISSN: 2672-7439

(C) 2018, UCTS Publisher.

Submitted: $11^{\text {th }}$ November $2020 \quad$ Accepted: $17^{\text {th }}$ December $2020 \quad$ Published: $31^{\text {st }}$ January 2021

\title{
Evaluation of Mycolytic Enzymes Producing Bacteria and their Potentials as Biocontrol Agents against Ganoderma boninense
}

\author{
${ }^{1}$ Wee Shui Shui, ${ }^{1}$ Izzatie binti Musa, ${ }^{1}$ Karen Yong, ${ }^{1}$ Kelvin Ling Wen Sin, and ${ }^{1,2}$ Peter Morin Nissom \\ ${ }^{1}$ School of Chemical Engineering and Science, Swinburne University of Technology, Sarawak Campus, Jalan \\ Simpang Tiga 93350 Kuching, Sarawak, Malaysia. \\ ${ }^{2}$ Sarawak Research and Development Council, Ministry of Education, Science and Technological Research, \\ LCDA Tower, off Jalan Bako, 93050, Kuching Sarawak, Malaysia.
}

\begin{abstract}
Basal stem rot (BSR) disease caused by white rot fungus, Ganoderma boninense causes great economic losses to the oil palm industries in Malaysia and other Southeast Asian countries. Traditionally, chemical fungicides are used to control BSR diseases, however, they do carry other side effects to both the environment and human health. This brings in the suggestion of the application of biocontrol agents as they are a more environmentallyfriendly approach. This study discusses the use of an environmentally-friendly approach to treat BSR with the application of biocontrol agents. Microbes that produce mycolytic enzymes were targeted due to their ability to degrade the fungal cell wall composition. Thus, protease- and glucanase-producing microbes were the focus in this study. The microbes were successfully isolated out from the local soil samples collected in Sarawak. A total of 21 out of 46 isolates were protease-producing microbes whereas the other 25 isolates were glucanase-producing microbes. The selective media Carboxymethylcellulose agar and Skim milk agar were used in the screening experiment. The antifungal properties of the potential bacterial isolates were tested against Ganoderma boninense by dual culture test. Among all the isolated strains, Pseudomonas putida showed the highest PIDG which was $86.3 \%$. The isolated strains showed promising results in anti-Ganoderma testing.
\end{abstract}

Keywords: Basal stem rot (BSR), Ganoderma boninense, mycolytic enzymes producing bacteria, biological control

\section{INTRODUCTION}

Malaysia and Indonesia cover about $83 \%$ of the world's total production of palm oil [6]. According to Malaysian Palm Oil Council [13], Malaysia is one of the largest palm oil exporters in the world contributing to about $33 \%$ of world export and $28 \%$ of world palm oil production. The major challenge faced by the oil palm industries lately is basal stem rot disease (BSR), caused by white rot fungus, Ganoderma boninense ( $G$. boninense). The BSR disease causes economic losses in oil palm industries of various regions around the world, which includes Southeast Asian countries as well [16].

The phytopathogenic fungus $G$. boninense, also known as white rot fungus, is a soil-borne fungus. In recent years, $G$. boninense has been found in younger plants and even in the seedlings of oil palms. The first sign of the basal stem rot disease shows the yellowing of the young fronds [17]. According to a previous study, it is believed that the spreading method of basal stem rot disease was through root-to-root method by the contact of the adjacent root [15]. Chemical, cultural, and mechanical control were conducted on the basal stem as disease management in oil palm cultivation but none of the control practices have shown satisfactory results in the disease management [17].

The traditional practice of using chemical fungicide, with the injection of a combination of carboxin and quintozene fungicides into the trunk, shows significant results in reducing BSR incidence [15]. However, the use of chemical fungicides causes adverse effects on the environment [7]. Besides that, the chemical fungicides are costly and may eventually induce the pathogen's resistance to said fungicides. Therefore, the use of biological control to suppress the plant diseases is an environmentally-friendly approach to controlling the phytopathogens in the agricultural industry [18].

Antagonistic activity of microbes is the most common approach of biological control which involves the secretion of secondary metabolites of one or more microbes that cause toxicity towards other microbes [1].

Corresponding Author: Peter Morin Nissom. Sarawak Research and Development Council,

Email:pnissom@gmail.com 
The antagonistic microbes possess the ability to produce certain secondary metabolites such as antibiotic, mycolytic enzymes, and volatile compounds with antibacterial or antifungal properties [20]. Numerous of such biological control agents have been reported in previous studies such as Pseudomonas spp., Bacillus spp., and Trichoderma spp. The antagonistic microbes that have the ability to produce mycolytic enzymes are able to degrade the cell wall of pathogenic fungi [1]. Study conducted by Muniroh et al., [14], stated that Pseudomonas aeruginosa and Trichoderma asperellum were able to suppress the growth of $G$. boninense by secreting protease, glucanase and cellulase in combating pathogen infection.

Chitin and $\beta-1,3$-glucan are the major cell wall components of the fungal cell wall [19]. Mycolytic enzymes' base formulation consists of chitinases, proteases, and glucanases which have been used in the control of fungal plant pathogens [7]. Due to the capabilities of the mycolytic enzymes produced by certain microbes to degrade the fungal cell wall, they could be the ideal candidates as potential biological control agents in the basal stem rot disease management in oil palm cultivation. Since there were ample studies on chitinase enzyme while less on glucanases and proteases enzymes as biocontrol agents [7], therefore, the main idea of this study was mainly focused on isolation of microbes with the ability to secrete glucanase and protease enzymes.

Furthermore, microbes that colonize around rhizospheres are ideal to be used as biological control agents. The rhizosphere serves as the first line of defence for the roots system of the plants against attack by pathogenic microorganisms [23]. Therefore, the rhizosphere microorganisms are the ideal candidates for biological control agents to suppress the soil borne pathogens. The rhizobacteria, Bacillus spp., Serratia spp., and Pseudomonas spp. has shown to be effective biological control agents against Fusarium. oxysporum $f$. sp melonis, the causative agent of Fusarium wilt in Rock melon [4]. The rhizobacteria such as Serratia spp. has been reported to act as biological control agents against nematodes, and also as plant growth enhancer, under greenhouse conditions [2]. This paper reports the isolation and characterisation of microbes that produce mycolytic enzymes from the soil ecosystem in Sarawak and the evaluation of their potential as biological control agents against, $G$. boninense.

\section{MATERIALS AND METHODS}

\section{Sampling, Screening, and Isolation of pure bacteria} strains from samples
Soil samples were collected at random from 4 locations, namely, Fairy cave Nature Reserve Park, Betong, Padawan, and Swinburne University of Technology, Sarawak campus at the rhizosphere; all locations are within Sarawak. The serial dilution plating technique was performed in the screening processes. Skim milk agar (SMA) (Difco, New Jersey, NY) and Carboxymethylcellulose agar (CMC) (Sigma-Aldrich, St Louis., USA) were chosen as the selection media. Skim milk agar (SMA) and Carboxymethylcellulose agar (CMC) were chosen for primary screening of protease- and glucanase-producing strains from the soil samples collected. SMA plates were used to screen for protease-producing bacteria while CMC plates were used to screen for glucanase-producing bacteria. SMA was commonly used to demonstrate coagulation and proteolysis of casein while CMC was used to examine the isolated strains for glucanase activity. The diluted factors $10^{-1}, 10^{-3}, 10^{-5}$, and $10^{-6}$ microbes were chosen and spread evenly in plates and incubated at $35^{\circ} \mathrm{c} \pm 2^{\circ} \mathrm{C}$ for three days. The potential microbial producers of protease and glucanase enzymes were determined from the sight of a clear zone formation area around certain bacterial colonies present on the SMA and CMC screening plates. The incubated plates were observed for the purity of the bacteria based on morphology and enzyme activity on the selective media. The purification step was done by repeated streaking of the bacterial colony of interest onto new selective media until the growth of colony was uniform on the plate. Contaminated microbes were eliminated at each of the streaked process. The pure cultures of mycolytic enzymes producing bacteria obtained were then coded. Glucanase enzyme-producing microbes were coded as $\mathrm{C} 1$ until $\mathrm{C} 24$ and protease enzyme-producing microbes were coded as S1 to S21 respectively.

\section{Molecular Identification by 16 S rDNA sequencing}

The selected pure bacteria strains were identified by $16 \mathrm{~S}$ rDNA sequencing analysis. The genomic DNA of pure bacteria strains were extracted by using genomic DNA purification kit (Fermentas, USA). The bacteria's DNA was amplified by polymerase chain reaction (PCR). Universal primer sets, 8 F (5'AGAGTTTGATCCTGGCTCAG-3') and 519 R (5'GWATTACCGCGGCKGCTG- 3') [22], targeting $16 \mathrm{~s}$ rRNA sequences were selected. MyTaq Red Mix (Bioline, USA) was used in PCR amplification according to the manufacturer's instructions. The PCR master mix contained the following: MyTaq Red Mix $(25 \mu \mathrm{L})$, forward primer $(1 \mu \mathrm{L}, 20 \mu \mathrm{M})$, reverse primer, $(1 \mu \mathrm{L}, 20 \mu \mathrm{M})$, and sterilized MilliQ water $(18 \mu \mathrm{L})$. Each PCR tube contained $45 \mu \mathrm{L}$ of master mix and were added with $5 \mu \mathrm{L}$ of crude DNA extract. DNA 
amplification was performed using a MasterCycler Gradient Thermal Cycler (Eppendorf, Germany) with the following cycling conditions: initial denaturation at $95^{\circ} \mathrm{C}$ for 1 minute followed by 29 cycles of denaturation process at $95^{\circ} \mathrm{C}$ for 15 seconds, annealing process at $55^{\circ} \mathrm{C}$ for 15 seconds and an extension process at $72^{\circ} \mathrm{C}$ for 15 seconds and, lastly, a final elongation process at $72^{\circ} \mathrm{C}$ for 5 minutes. The final PCR amplified products were analysed on a $1 \%(w / v)$ agarose gel and added with $3 \mu \mathrm{L}$ of Midori stain (Nippon Genetics Europe GmBH, Duren, Germany for better visualization under the UV light. The gel image of PCR products were visual and captured by Gel Documentation EQ System for DNA/ RNA Gel Photos (Bio- Rad, USA). The final PCR products were sent to First Base Laboratories Sdn Bhd, Selangor, Malaysia for DNA sequencing analysis. The sequenced results obtained were analysed by matching them to the known 16s rRNA gene sequences in the Genbank database [5] using BLAST (Basic Local Alignment Search Tool) of the National Centre for Biotechnology Information [10]. Mega 6 was used to create a phylogenetic tree by the use of the maximum likelihood method [21].

Evaluation of the In Vitro Antifungal Activity of the Bacterial Isolates against Plant Pathogenic Fungi, Ganoderma boninense

The dual culture test was adapted to be used for the evaluation of the antagonistic activity of the protease and glucanase enzyme-producing bacterial isolates against plant pathogenic fungi, G. boninense [4]. The Nutrient Agar (NA) media plates were divided into half and labelled. The 16 different isolated strains were inoculated onto NA media plates by a single streak in the middle on the half side of the NA plates. An agar plug from a 5-day old $G$. boninense culture plate was placed in the middle of the other half side of the NA plates. As for control plates, an agar plug was transferred from 5 days old $G$. boninense culture plate and placed in the middle of NA media plate without the presence of isolated bacterial strains. The inoculated plates were then incubated in the incubation room at $35^{\circ} \mathrm{C} \pm 2{ }^{\circ} \mathrm{C}$ for 7 days. The plates were observed and measured on the $3^{\text {rd }}$ and $7^{\text {th }}$ day. Three replicates were made for each test strain plate as well as the control plates. The microbial inhibitions activities were observed by measuring the diameter of the inhibition zones. After 7 days, the diameter growth of $G$. boninense was measured. The percentage inhibition of diameter growth (PIDG) was calculated according to the equation [10] as follows:

Percentage Inhibition of Diameter Growth $=[\mathrm{C}$ $\mathrm{T}] / \mathrm{C} \times 100$

Where;
C - Diameter growth of $G$. boninense in the control plate

$\mathrm{T}$ - Diameter growth of $G$. boninense in the test plate

\section{Statistical Analysis}

Data collected were processed and analysed primarily using MS Excel.

\section{RESULTS AND DISCUSSION}

\section{Sampling, Screening, and Isolation of pure bacteria strains from samples}

The soil samples were collected from various locations within Sarawak. Mycolytic enzyme producing bacteria were targeted due to its ability to synthesize enzymes that can degrade the cell wall of plant pathogenic fungi [1]. Previous studies have shown that the mycolytic enzymes increase in large amounts at infected areas of plants when the defence response gene of the infected plants are triggered [15]. Mycolytic enzymes' base formulation consisting of proteases and glucanases have been used in the control of plant pathogenic fungi [7] As shown in Figure 1, the clear zone formations on SMA (A) plates indicated the presence of protease enzymes as the protein content, casein within the media had degraded. The isolated bacteria hydrolyzed casein into soluble nitrogenous compounds thus resulting in the formation of the clear zones observed [9]. Similarly, the formation of clear zone in CMC (B) agar plates in Figure 1 showed that there were hydrolysis activities of $\beta$-1,3-glucan. It indicated the presence of glucanase enzymes secreted by test strains [8]. The microbes of interests with clear zone formation as shown in Figure 1 were inoculated to new SMA and CMC agar plates for pure culture isolation.

\section{Molecular Identification by $16 S$ rDNA sequencing}

The isolates were identified using molecular identification via DNA sequencing of the 16s rRNA gene sequence. The crude DNA for the 46 isolates were successfully extracted by the use of DNA extractions kits and also freeze and thaw method. The selected universal primers sets, $8 \mathrm{~F}$ and $519 \mathrm{R}$ were used to target the 16s rRNA sequences. PCR products size obtained for the isolates were approximately 500bp. The microbes were identified to species level based on the reference of query cover and identity percentage which is not less than $70 \%$ for both percentage. The isolates were selected based on the closest match and the accession number for the closest match species were indicated. On the basis of the partial 16s rRNA 
sequence comparison results in Table 1, Figure 3 and 4, the isolates bacteria were classified to be members of the genus of Bacillus, Delftia, Acinetobacter, Stenotrophomonas, Ralstonia, Burkholderia, Pseudomonas, Serratia, Staphylococcus, and Chryseobacterium.

\section{Evaluation of the In Vitro Antifungal Activity of the Bacterial Isolates against Plant Pathogenic Fungi, Ganoderma boninense}

Dual culture plate assay was adapted to be used in this study. The comparison of the growth of phytopathogenic fungi, $G$. boninense in control and test plate is presented in Figure 2. The PIDG of 16 different isolated strains were calculated according to the growth diameter $(\mathrm{cm})$ results at day 7 of the anti-Ganoderma experiment as shown in Figure 2. The results of PIDG for 16 different isolated strains are presented in Figure 5. The results showed that Pseudomonas putida, Bacillus cereus, Serratia marcescens, Chryseobacterium indologenes, Acinetobacter calcoaceticus, and Bacillus flexus had higher PIDG rate when compared to the other isolated strains. The PIDG for $P$. putida showed highest PIDG amongst all isolated strains which was $86.3 \%$. The PIDG for $P$. putida is then followed up by $B$. cereus and $S$. marcescens where the PIDG for both strains were $85.8 \%$ and $84.7 \%$. $C$. indologenes, A. calcoaceticus, and B. flexus isolates showed almost similar PIDG results in the antiGanoderma test which were $83.7 \%, 82.8 \%$, and $82.0 \%$ respectively. Bacillus spp., Serattia spp. and Pseudomonas spp. has been reported to act as biocontrol agents in previous studies. The modes of action involves the production of antibiotic (iturin, surfactin, and fengycin), the secretion of the mycolytic enzymes (chitinases, glucanases, and proteases) that have the capabilities to degrade fungi cell wall, and also volatile compounds that possess antifungal or

\section{REFERENCES}

[1] Alabouvette, C., Olivain, C., and Steinberg, C. 2006. Biological control of plant diseases. The European situation. Eur. J. Plant Pathol., 114, 329341.

[2] Almaghrabi, O.A., Massoud, S.I. and Abdelmoneim, T.S. 2013. Influence of inoculation with plant growth promoting rhizobacteria (PGPR) on tomato plant growth and nematode reproduction under greenhouse conditions. Saudi J. Biol. Sci., 20, 57-61.

[3] Arrebola, E., Sivakumar, D. and Korsten, L. 2010. Effect of volatile compounds produced by antimicrobial properties. In addition, the secondary metabolites secreted are able to enhance the plant growth and improve the defence responses systems in the host plant [3]. In previous studies, the antifungal mechanism of Serratia spp. was described to be direct antifungal properties based on the antibiosis activity and the production of mycolytic enzymes such as chitinases and $\beta$-1, 3-glucanases [12]. The Pseudomonas spp. have been described to be responsible for the natural suppression of some plant diseases caused by soil-borne pathogens [24].

\section{CONCLUSION}

The screening of the bacterial strains from Sarawak's soil samples that produce protease and glucanase enzymes showed their anti-fungal properties against phytopathogenic fungus, $G$. boninense. The findings obtained in this study describes the potential use of the protease- and glucanase-producing bacteria as biological control agents towards $G$. boninense. Combination of different assays to further evaluate the efficiency of the isolated strains as biological control agents and greenhouse studies are required.

\section{ACKNOWLEDGMENT}

This research was supported by the Biotech Alliance International Sdn. Bhd. and Swinburne University of Technology (Sarawak Campus) under Swinburne Sarawak Research Grant (SSRG 2-5604). We thank to the staffs of Biotechnology laboratory and School of Chemical Engineering and Science in Swinburne University of Technology (Sarawak Campus) for their valuable assistance throughout the project. We also thank Sarawak Biodiversity Council (SBC) for the research permit (SBC-RA-0109-PMN).

Bacillus strains on postharvest decay in citrus. Biol. Control, 53, 122-128.

[4] Elmahdi, S., Kadir, J., Tengku, M., Mohamed, M., Vadamalai, G. and Akter, S. 2015. Isolation, Screening and Characterization of Effective Microbes with Potential for Biological Control of Fusarium wilt of Rock Melon. World Journal of Agricultural Research, 3(1), 11-16.

[5] Geer, L.Y., Marchler-Bauer, A., Geer, R.C., Han, L., He, J., He, S., Liu, C., Shi, W. and Bryant, S.H. 2009. The NCBI BioSystems database. Nucleic Acids Res. 38, 492-496. 
[6] Global Palm Oil Conference. 2015. Background Document: An Overview of the Palm Oil Sector: Countries and Companies. Global Palm Oil Conference, Bogota, Columbia. 12-13 March 2015.

[7] Gohel, V., Singh, A., Vimal, M., Ashwini, P. and Chhatpar, H.S. 2006. Bioprospecting and antifungal potential of chitinolytic microorganisms. African J. Biotechnology, 5, 54-72.

[8] Gohel, H.R., Contractor, C.N., Ghosh, S.K. and Braganza, V.J. 2014. A comparative study of various staining techniques for determination of extra cellular cellulase activity on Carboxy Methyl Cellulose (CMC) agar plates. Int. J. Curr. Microbiol. Appl. Sci., 3, 261-266.

[9] Himedia. 2018. Skim Milk Agar, Technical Data Sheet. $\quad$ http://himedialabs.com/td/m763.pdf. Accessed on 1 July 2020.

[10] Himratul-Aznita W.H., Mohd-Al-Faisal N. and Fathilah A.R. 2011. Determination of the percentage inhibition of diameter growth (PIDG) of Piper betle crude aqueous extract against oral Candida species. J. Med. Plants Res. 5(6), 878884.

[11] Johnson, M., Zaretskaya, I., Raytselis, Y., Merezhuk, Y., McGinnis, S. and Madden, T.L. 2008. NCBI BLAST: a better web interface. Nucleic Acids Res. 36, 5-9.

[12] Kalbe, C., Marten, P. and Berg, G. 1996. Strains of the genus Serratia as beneficial rhizobacteria of oilseed rape with antifungal properties. Microbiol. Res., 151, 433-439.

[13] Malaysian Palm Oil Council. 2020. Malaysian Palm Oil Industry. http://mpoc.org.my/malaysianpalm-oil-industry/\#. Accessed on 1 July 2020.

[14] Muniroh, M.S., Nusaibah, S.A., Vadamalai, G., and Siddique, Y. 2019. Proficiency of biocontrol agents as plant growth promoters and hydrolytic enzyme producers in Ganoderma boninense infected oil palm seedlings. Current Plant Biology, 20, 100116. doi:10.1016/j.cpb.2019.100116

[15] Naher, L., Yusuf, U.K., Ismail, A., Tan, S.G. and Mondal, M.M.A. 2013. Review Article Ecological status of Ganoderma and basal stem rot disease of oil palms (Elaeis guineensis Jacq.). Aust. J. Crop Sci., 7, 1723-1727.
[16] Paterson, R.R.M. 2007. Ganoderma disease of oil palm-A white rot perspective necessary for integrated control. Crop Prot. 26, 1369-1376.

[17] Sanderson, F.R. 2005. An insight into spore dispersal of Ganoderma boninense on oil palm. Mycopathologia, 159, 139-141.

[18] San-Lang, W., Shih, I.L., Wang, C.H., Tseng, K.C., Chang, W.T., Twu, Y.K., Ro, J.J. and Wang, C.L. 2002. Production of antifungal compounds from chitin by Bacillus subtilis. Enzyme Microb. Technol., 31, 321-328.

[19] Solanki, M.K., Robert, A.S., Singh, R.K., Kumar, S., Pandey, A.K., Srivastava, A.K. and Arora, D.K. 2012. Characterization of mycolytic enzymes of Bacillus strains and their bio-protection role against Rhizoctonia solani in tomato. Curr. Microbiol., 65, 330-336.

[20] Suryanto, D., Irawati, N. and Munir, E. 2011. Isolation and Characterization of Chitinolytic Bacteria and Their Potential to Inhibit Plant Pathogenic Fungi. Microbiol. Indones. 5, 144148.

[21] Tamura, K., Stecher, G., Peterson, D., Filipski, A. and Kumar, S. 2013. MEGA6: Molecular evolutionary genetics analysis version 6.0. Mol. Biol. Evol. 30, 2725-2729.

[22] Turner, S., Pryer, K.M., Miao, V.P. and Palmer, J.D. 1999. Investigating deep phylogenetic relationships among cyanobacteria and plastids by small subunit rRNA sequence analysis. J. Eukaryot. Microbiol. 46, 327-338.

[23] Weller, D.M. 1988. Biological control of soilborne plant pathogens in the Rhizosphere with Bacteria. Ann. Rev. Phytopathol. 26, 379-407.

[24] Weller, D.M. 2007. Pseudomonas biocontrol agents of soilborne pathogens: looking back over 30 years. Phytopathol, 97, 250-256. 

boninense

\section{APPENDIX}

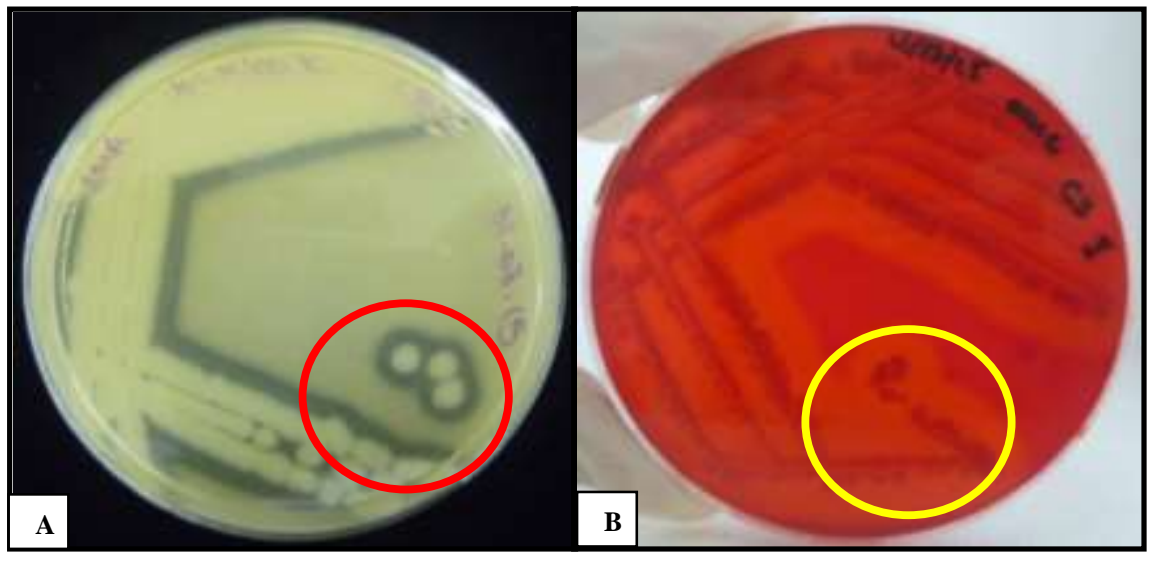

Figure 1: Screening for potential protease- and glucanase-producing microbes. The formation of a clear zone by potential isolates on selective media SMA (A) and CMC (B) agar plates indicate positive mycolytic enzyme production.

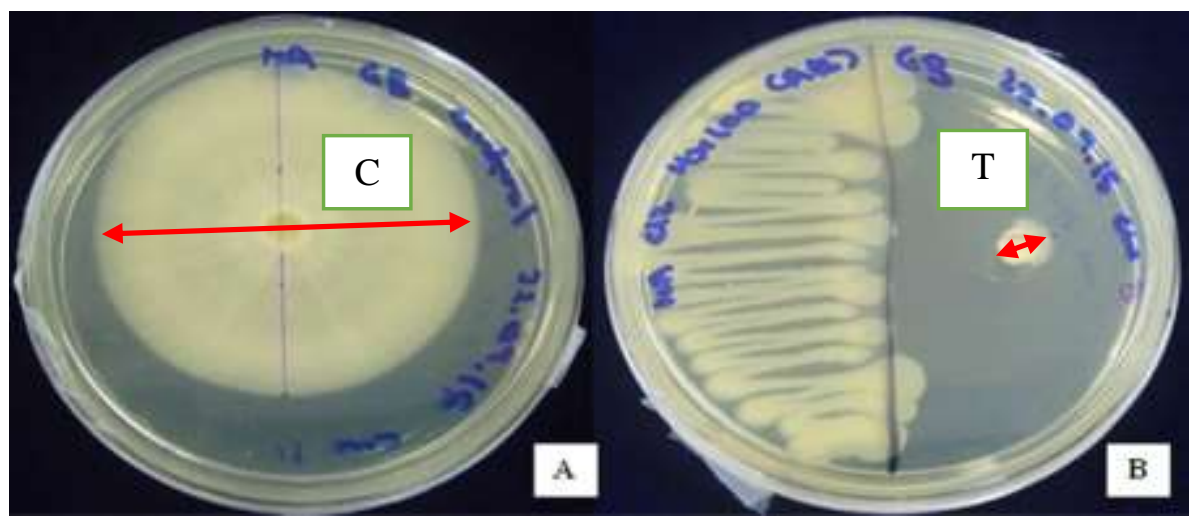

Figure 2: Dual culture plate assay to evaluate the efficiency of the isolated strains inhibiting the growth of the phytopathogenic fungi, G. boninense. The comparison of the mycelial growth of phytopathogenic fungi, $G$. boninense, in control plate (A) and test plate with the presence of B. cereus, C12 (B) at day 7. C is the diameter growth of $G$. boninense in the control plate, T represents the diameter growth of $G$. boninense in the test plate. 


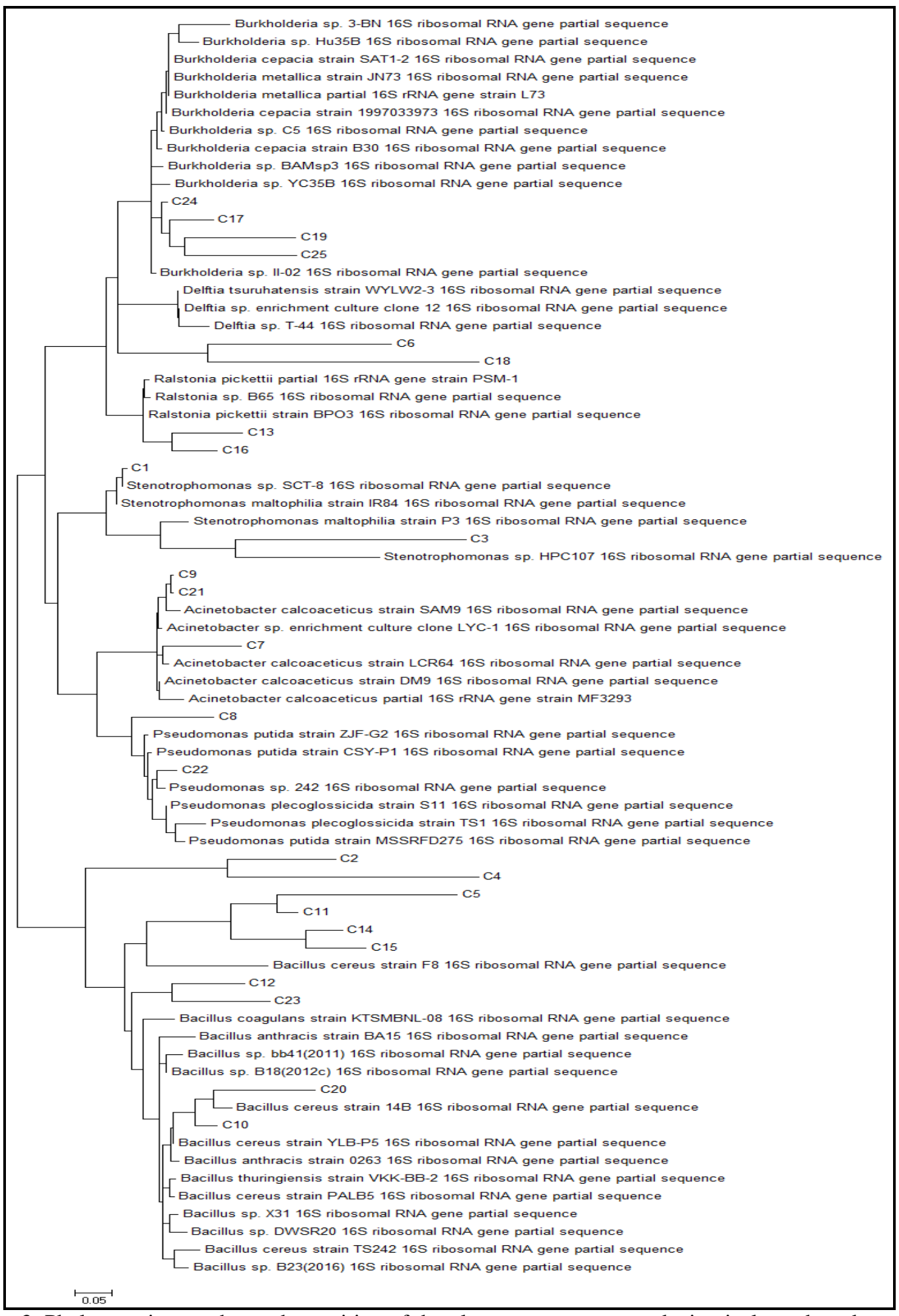

Figure 3: Phylogenetic tree shows the position of the glucanase enzyme-producing isolates, based on the partial 16 s rRNA sequence comparison. The phylogenetic tree was constructed based on Maximum Likelihood method. 


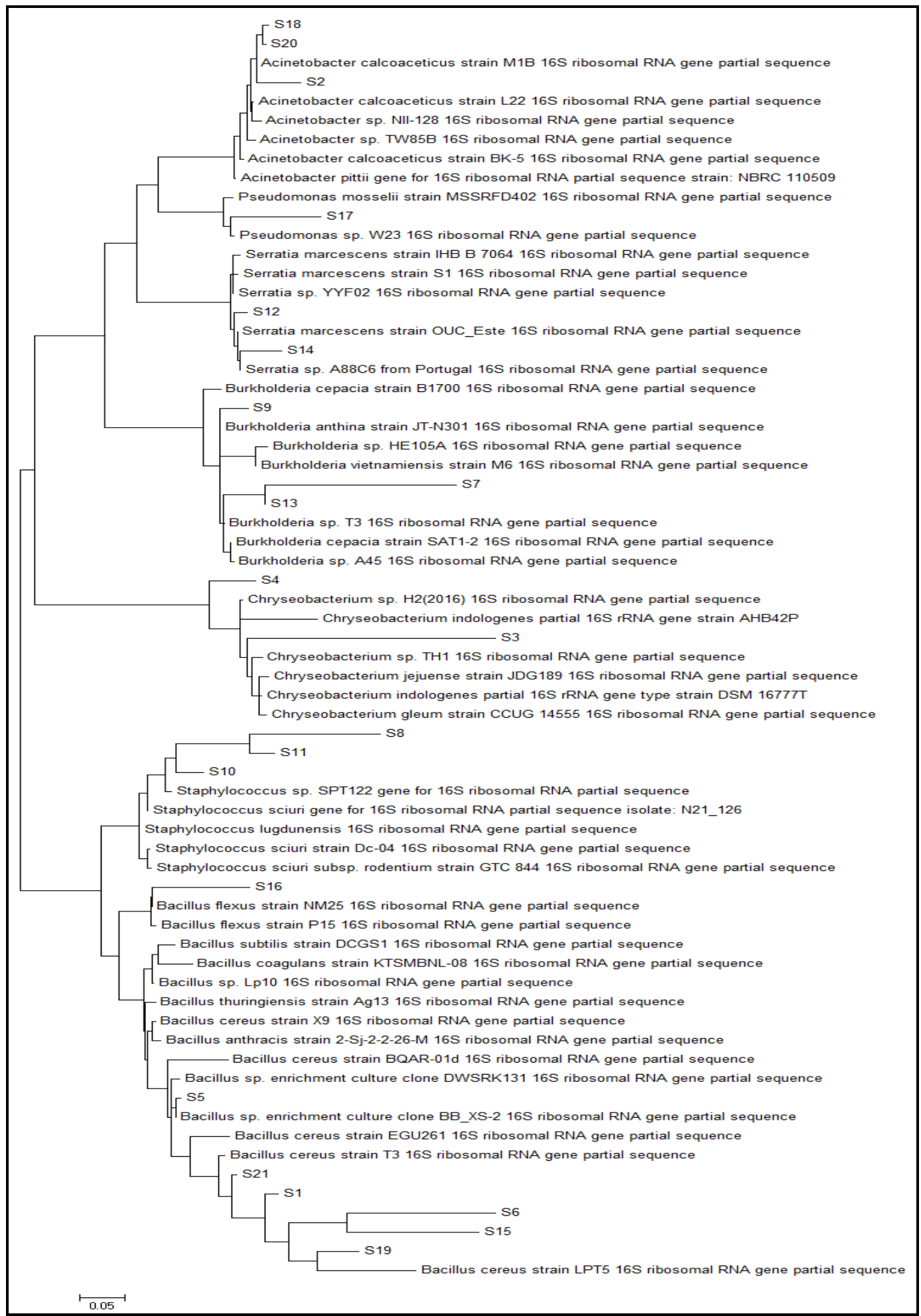

Figure 4: Phylogenetic tree shows the position of the protease enzyme-producing isolates, based on the partial 16s rRNA sequence comparison. The phylogenetic tree was constructed based on Maximum Likelihood method. 
Evaluation of Mycolytic Enzymes Producing Bacteria and their Potentials as Biocontrol Agents against Ganoderma boninense

Table 1: The closest match of the strains' identity obtained after comparison with Genbank database.

\begin{tabular}{|c|c|c|}
\hline Strain species & Strains identity obtained & Number of isolates \\
\hline \multirow{4}{*}{ Bacillus spp. } & Bacillus cereus & 9 \\
\hline & Bacillus coagulans & 3 \\
\hline & Bacillus flexus & 1 \\
\hline & Bacillus anthracis & 3 \\
\hline Delftia spp. & Delftia tsuruhatensis & 1 \\
\hline Acinetobacter spp. & Acinetobacter calcoaceticus & 6 \\
\hline Stenotrophomonas spp. & Stenotrophomonas maltophilia & 2 \\
\hline \multirow[t]{2}{*}{ Ralstonia spp. } & Ralstonia pickettii & 2 \\
\hline & Burkholderia metallica & 1 \\
\hline \multicolumn{3}{|l|}{ Burkholderia spp. } \\
\hline & Burkholderia cepacia & 7 \\
\hline & Pseudomonas plecoglossicida & 1 \\
\hline \multirow[t]{2}{*}{ Pseudomonas spp. } & Pseudomonas mosselii & 1 \\
\hline & Pseudomonas putida & 2 \\
\hline Serratia spp. & Serratia marcescens & 2 \\
\hline Staphylococcus spp. & Staphylococcus sciuri & 3 \\
\hline Chryseobacterium spp. & Chryseobacterium indologenes & 2 \\
\hline
\end{tabular}


Evaluation of Mycolytic Enzymes Producing Bacteria and their Potentials as Biocontrol Agents against Ganoderma boninense

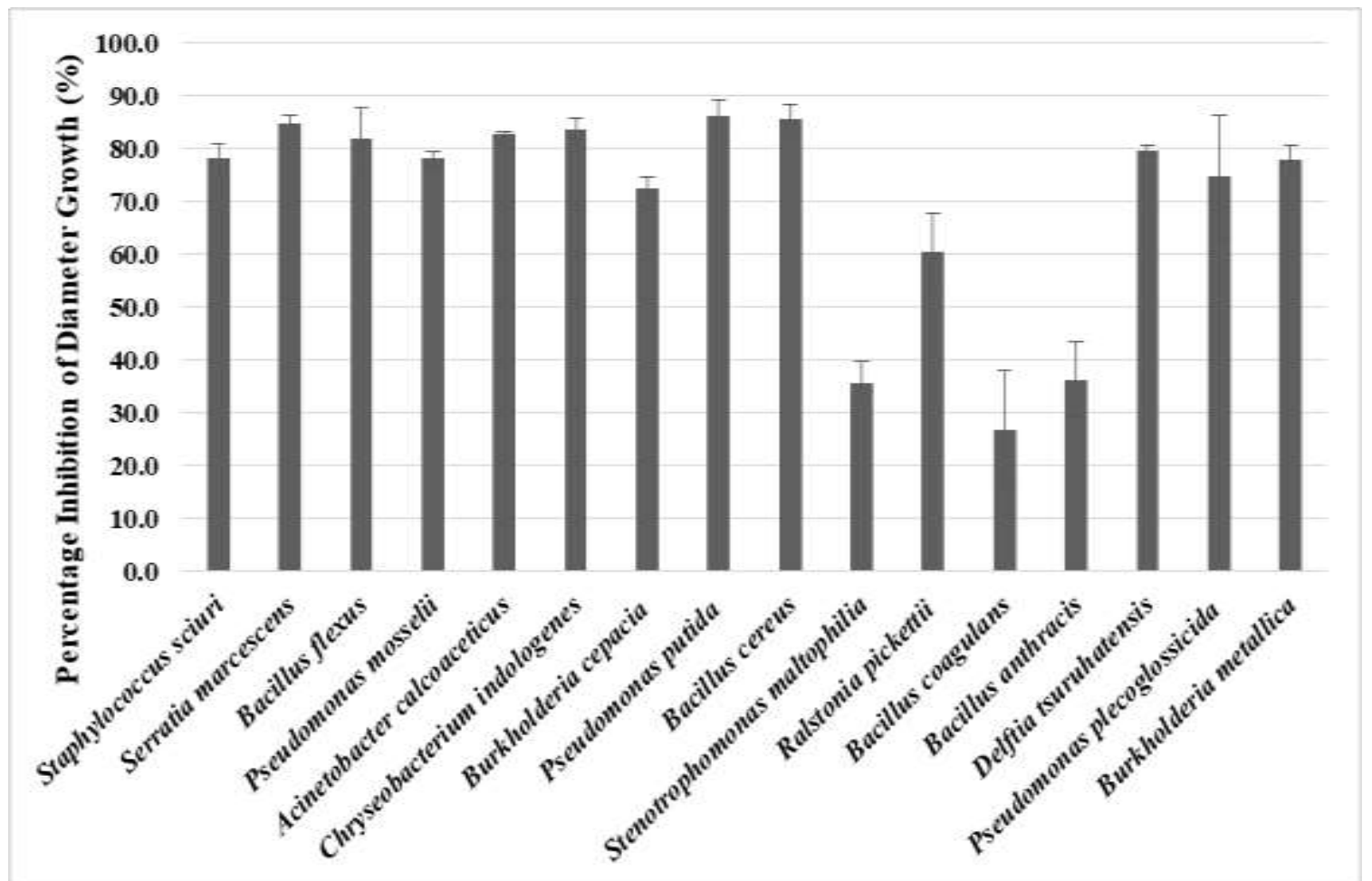

Figure 5: Percentage inhibition of diameter growth (PIDG) results on the 7th day of the anti-Ganoderma experiment. The 16 different isolated strains tested against phytopathogenic fungi, G. boninense. 